\title{
Securing the Maritime Domain: U.S. and New Zealand in a Bordered Pacific
}

\author{
Author: Nicklin, Germana
}

To cite this article: Nicklin, G. (2021). Securing the Maritime Domain: U.S. and New Zealand in a Bordered Pacific. National Security Journal, 3(2). doi: 10.36878/nsj20210317.03

To link to this article: https://doi.org/10.36878/nsj20210317.03

View CrossRef data: https://search.crossref.org/?q=10.36878\%2Fnsj20210317.03 


\title{
SECURING THE MARITIME DOMAIN: U.S. AND NEW ZEALAND IN A BORDERED PACIFIC
}

\author{
Germana Nicklin ${ }^{1}$
}

\begin{abstract}
Maritime security in the Pacific differs according to whose security is under threat and in what geographical location. Like the fluidity of the ocean, maritime security is dynamic involving multiple interests. But the Pacific is also a very bordered space. Drawing on a December 2019 study tour of US defence facilities in Hawai' $i$, this article addresses the question "How are United States (US) and New Zealand maritime security interests bordered in the Pacific and what are the implications?" First, the article situates maritime security within state territoriality and defence of borders. It then examines the Pacific Ocean as a bordered space, and sketches US and New Zealand interests within it, including differentiating Indo-Pacific from Pacific. Next, each country's means of securing their maritime domains in the Pacific is explicated, the arenas of cooperation and gaps in knowledge worth researching further. It concludes by discussing US-NZ maritime cooperation within the framing of a Pacific maritime borderscape. One potential borderscape is the Polynesian Triangle. This article argues that defining a specifically bordered theatre of cooperation such as the Polynesian Triangle, driven by Pacific Island needs, is required to provide balance and visibility to non-military maritime security matters. Such a theatre of cooperation warrants further research.
\end{abstract}

Keywords: Maritime security; Pacific; borderscape; Indo-Pacific; United States; New Zealand

\section{Introduction}

The Pacific Ocean is a geographical space dominated by narratives of human crossings trade, migrations, and the exercise of maritime power. Maritime power and its potential effect on trade routes in the Pacific region has dominated $21^{\text {st }}$ century narratives, opposing one side of the Pacific Ocean against the other, specifically China and the United States. ${ }^{1}$ This opposition is potentially destabilising for the region, but there are other important dynamics, particularly for New Zealand, that get far less attention.

1 Dr Germana Nicklin, is Senior Lecturer at Massey University. She can be reached at g.nicklin@massey.ac.nz. 
One area in which these other dynamics play out is non-military maritime security, epitomised by the Boe Declaration on Regional Security signed by Pacific Island Forum leaders in 2018. ${ }^{2}$

A study tour of United States defence facilities in Hawai'i from 9-13 December 2019 provided the author with a unique opportunity to enter the maritime security world of one of the great powers in the region - the United States (US) and to reflect on its connection with New Zealand. Hawaii is strategically positioned geographically for the deployment of military and non-military capabilities into Asia and the North West Pacific. Significant naval and air-borne craft are stationed in Hawai' i. One of the non-military capabilities stationed there is the US Coast Guard.

Stimulated by this study tour, this article addresses the question "How are US and New Zealand maritime security interests bordered in the Pacific and what are the implications?" It does not examine the nature of maritime threats, which are covered well elsewhere, but rather focuses on the Pacific maritime security arena. First, the article situates maritime security within state territoriality and defence of borders. It then examines the Pacific Ocean as a bordered space, and sketches US and New Zealand interests within it, including differentiating Indo-Pacific from Pacific. Next, each country's means of securing their maritime domains in the Pacific is explicated, and the arenas of cooperation. It concludes by discussing US-NZ maritime cooperation within the framing of a Pacific maritime borderscape. It argues that defining a specifically bordered theatre of cooperation driven by Pacific Island needs is required to provide balance and visibility to non-military maritime security matters. Such a theatre of cooperation warrants further research.

\section{Maritime territoriality, borders and security}

Maritime security cannot be understood without considering its relationship with the land and with state borders. Modern concepts of state sovereignty include principles of mutual acceptance of territory and non-interference in other states' affairs. ${ }^{3} \mathrm{~A}$ key aspect of state sovereignty is securing state borders through exercising territoriality. Territoriality is about having, or attempting to have, power over a geographical space, with studies of territoriality focusing on land rather than maritime zones. ${ }^{4}$ Since World War II, the management of state borders has undergone significant change, particularly from the creation of the supranational body of the European Union. As a result, state borders have been reconceived as spaces, as performances and processes and as broad landscapes that encompass multiple actors and multiple sites. ${ }^{5}$ These different conceptions of borders acknowledge them as dynamic places of movement and contestation. Flows across borders exercised on land represent both risks and benefits to states; policies about securing borders tend to reflect societal values about identity and belonging, implying a sense of permanence and order. ${ }^{6}$ By comparison, the maritime domain is 
fluid and its permanent populations are ocean wildlife, not people. Considerations of the maritime domain as a bordered space were, until the mid- $20^{\text {th }}$ century, focused on seas close to states' territories. ${ }^{7}$

In 1982, as the culmination of over 20 years' work to order the maritime domain, the United Nations Convention on the Law of the Sea (UNCLOS) completely transformed the maritime domain as a space of state control, ordering it with borders somewhat equivalent to borders on land: "From a spatial perspective, UNCLOS III represents the

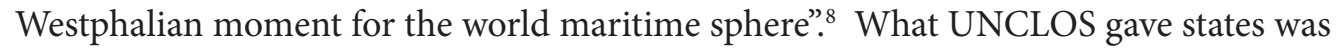
the ability to exercise territoriality over a range of maritime spaces defined in international law. ${ }^{9}$

UNCLOS bordered spaces operate on a continuum of different degrees of state control. A simple characterization of this continuum is that at one end, states have the same control from the coast out to 12 nautical miles as on land; at the other end, in the open seas, states have little territorial control. Figure 1 depicts the zones of territorial control along the continuum, with most control on the left, and least control on the right. It is worth noting that these zones of control are three dimensional, dropping below the sea down to the sea-bed at the bottom, out to the continental shelf and up to the air above. Under UNCLOS, the outer limit of state control of air space occurs at the $12 \mathrm{~nm}$ territorial sea border. Beyond that is international air space. Thus, UNCLOS creates a three-dimensional maritime domain situated on, above and below the sea with differing zones of state control.

Figure 1: Continuum of state maritime control.

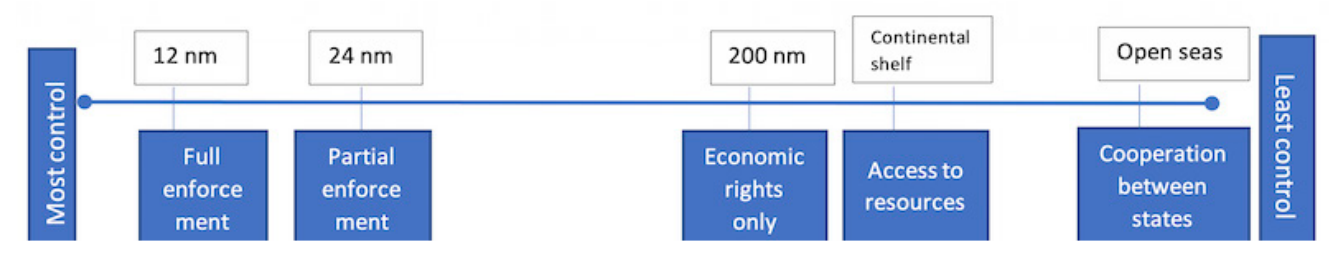

The effectiveness of the UNCLOS demarcation of spaces depends on signatory states to UNCLOS actively honouring their obligations, both through enacting provisions in their own legislation, and negotiating in good faith with states where any of these zones overlap. Examples of maritime spaces in which agreement has not been achieved and where political tensions are high are the East China Sea and the South China Sea. ${ }^{10}$ In both these spaces, China is intransigent, and the US is intervening even though it has 
no jurisdiction there. It is important to note that the US is not a signatory to UNCLOS, which creates an ironic situation where the US is promoting compliance with an instrument it is not a party to. Being a non-signatory arguably undermines its ability to be an advocate and to work to strengthen the agreement. ${ }^{11}$

Maintaining security over the different UNCLOS zones differs according to the degree of state control, as depicted on the continuum. Of all the zones, the open seas spaces are particularly interesting. First, they have no equivalent on land. All land except Antarctica has been divided into state territories. In open seas spaces, there is no ownership or absolute state control; there are no visible edges, such that 'inside' and 'outside' can be identified only with navigational instruments, and there is no state identity of 'us' and 'them'. Rather, identity is limited to ship flags and other identifiers on ocean vessels - practices that are subject to abuse and misuse under UNCLOS. ${ }^{12}$ Second, the materiality of the maritime domain as a bordered space is uncertain. ${ }^{13}$ Fluidity is a constant, with the ocean subject to the vagaries of the weather and state identity on the high seas shifting as vessels move from one place to another.

The term 'maritime security' is somewhat problematic in this three-dimensional, unpredictable space. Barry Ryan discusses maritime security as "good order at sea". ${ }^{14}$ This conception echoes the military history of maritime security, with its focus on maintaining the free passage of trade through naval command of the seas. ${ }^{15}$ Maritime security as a term, though, is static, implying a steady state - a place where the maritime domain is free of threats. Ideas of good order and command of the sea imply this steady state is possible. However, the discussion above highlights the inappropriateness of such a term, given the fluid nature of the maritime space, not helped by the fact that 'maritime' is an adjective and does not stand alone. ${ }^{16}$ For example, in answer to the question 'what is to be secured?', 'maritime' does not make sense - it begs the question 'maritime what?' Little surprise, then, that there is no agreed definition of the term 'maritime security. ${ }^{17}$ Along with being static, the term is also unbounded. For the purposes of this discussion, then, the phrase 'securing the maritime domain' will be used. 'Securing' is active, representing movement through process and changes of meaning and circumstance; 'domain' suggests a bounded space that can be controlled. In the present discussion, the bounding is that created by UNCLOS.

Maritime bordering is a core aspect of securing the maritime domain. The continuum of Figure 1 can also be represented as a series of concentric circles, with the territorial state at the centre. Each circle represents where and how a state can bound its oceanic space. Each of these bounded spaces is part of a state's maritime domain. Each of these bounded spaces has its own characteristics and scope for states to act. Bordering is the activity of controlling, and thus securing, movements across these bounded spaces within a state's maritime domain..$^{18}$ As such, maritime bordering involves multiple interests, from protecting the marine environment to national security. Securing 
maritime domains against threats to these interests tends to be similar across the world - preventing illegal activity, piracy, drug and arms smuggling, illegal migration, illegal resource exploitation, terrorism. ${ }^{19}$ These interests can and do intersect, creating both synergies and tensions. Notably, while involving territoriality, they are not necessarily territorial, especially when illegal activity is identified in the open seas.

For example, the US has no direct territorial interests in the South China Sea, but it has political, economic and military interests. It has a base in the Philippines, one of the claimant states; it supports the defence of Taiwan from invasion by mainland China. ${ }^{20}$ It has interests in keeping the trade route open through the South China Sea. As such, maritime security for the US in this location involves a naval presence for deterring and monitoring China's activities. ${ }^{21}$ Maritime security for China in the South China Sea is also about displaying its control of the maritime space through military presence, in line with its claim over the whole area. ${ }^{22}$ While navies are involved in both cases, there are differences in what is being secured and why.

Ranging from maritime ports out to the open seas, maritime border activities are arguably more challenging than on land, where physical barriers or choke points can more easily be created. International cooperation becomes particularly important in both deterring illegal activity and interdicting when illegal activity does occur, through maintaining a physical presence across an area and through information sharing. It can also involve military defence of maritime zones. An example of a synergy between military and civilian interests is the use of navies to combat piracy in order to secure the safe passage of commercial trade vessels. ${ }^{23}$ An example of tension is between military and civilian priorities for maritime security, particularly when navies' constabulary role is increasing. ${ }^{24}$

Core to addressing these interests is Maritime Domain Awareness (MDA). While the location of MDA depends on whose gaze is involved, it encompasses the common interests outlined above. In essence, MDA is about tracking the movement of vessels within a particular maritime domain, analysing any connections between those vessels, their crew, their cargoes and illicit activity, and predicting the routes of identified risk vessels. ${ }^{25}$ These activities are complicated by the fluidity of vessels, where much can change on route, such as the appearance, the route, the ship's flag and even the owners. Because the open seas fall outside state maritime domains, MDA on the open seas has to be achieved by way of information sharing and cooperation.

The next section examines the effects on securing the maritime domain from the Pacific Ocean as a particular bordered space. This examination provides the potential scope of US-New Zealand's theatre of cooperation. 


\section{The Pacific Ocean as a bordered space}

Geologically, the Pacific Ocean is bounded by a ring of active volcanoes and shifting tectonic plates, known as the Ring of Fire. ${ }^{26}$ This ring links most of the land masses that edge the Pacific Ocean. There is, then, a sense in which the Pacific Ocean is a geologically bounded space - a space that is volatile and unpredictable. Of note is that Australia is outside the Ring of Fire, located instead on the Indo-Australian tectonic plate.

Politically, the Pacific Ocean is bounded by the states that surround it - from Russia and China in the northwest to Canada and the United states in the northeast, down to Chile in the southeast and across to Malaysia in the southeast, incorporating the Oceanic states in between. The northern Pacific is dominated by large continental powers - Russia, China, Japan, the United States, Canada; the southern Pacific is populated by the island states of Oceania, with Australia, New Zealand and to some extent, France playing a prominent political role in the region. Beyond the maritime domains of these Pacific Rim states are large tracts of open seas.

The cartographical picture of Pacific Rim states encircling the almost uninhabited ocean suggests two states of 'being': first, their common connection to the Pacific Ocean, and second, the oceanic space as a space for them to control. Their connection contains aspects of identity - identity as Pacific Rim states; identity as northern or southern, eastern or western Pacific states. The author experienced this geographical identity acutely when visiting Hawai'i. The gaze of the US military there is primarily focused on the northwest and northeast Pacific with the east Pacific and US mainland at its back; the South Pacific that means so much to New Zealand was invisible. New Zealand's gaze is quite different - north to the Pacific Islands, west to Australia, south to Antarctica, and east to South America.

The two states' maritime domains and their near neighbourhoods are different; their security interests are similar but not the same. Following on from the question above - 'what is to be secured?' - the questions 'whose security?' and 'for what purpose?' are important in the context these interests. For example, as already noted, the US has no direct territorial interests in the South China Sea, but it has political and military interests. As such, securing the maritime domain for the US in this location involves a naval presence that monitors China's activities and acts as a deterrent presence. By comparison, New Zealand's primary interest is in maintaining a secure trade route through the South China Sea. This is at the same time economic and a political interest in a well-functioning international system, in relation to which China's non-compliance with UNCLOS is a problem. ${ }^{27}$ While somewhat simplistic, these depictions of interest highlight that differences sit alongside commonalities. The key point to note is that both provide opportunities for working together. One such opportunity sits within a maritime zone sometimes called the 'Polynesian Triangle'. 


\section{The Polynesian Triangle}

Polynesia is a sub-region of the Pacific signified by the flows of peoples between the islands within a triangular area, illustrated in Figure 2 below. ${ }^{28}$ This sub-region of the Pacific has Hawaii $i$ at the apex of the triangle in the north, New Zealand at the south west corner of the triangle and Rapanui Easter Island at the south east corner. Contained within the triangle are New Zealand's realm countries of Tokelau, Cook Islands and Niue, among others. Notably, France, another colonial power, also has territory in this triangle. The borders of the triangle are conceptual, traced by the historical movements of craft from one island group to another; the borders are also cultural, with foreigners who travelled between these island groups having identified similarities in language and practices. ${ }^{29}$

Figure 2: The Polynesian Triangle.

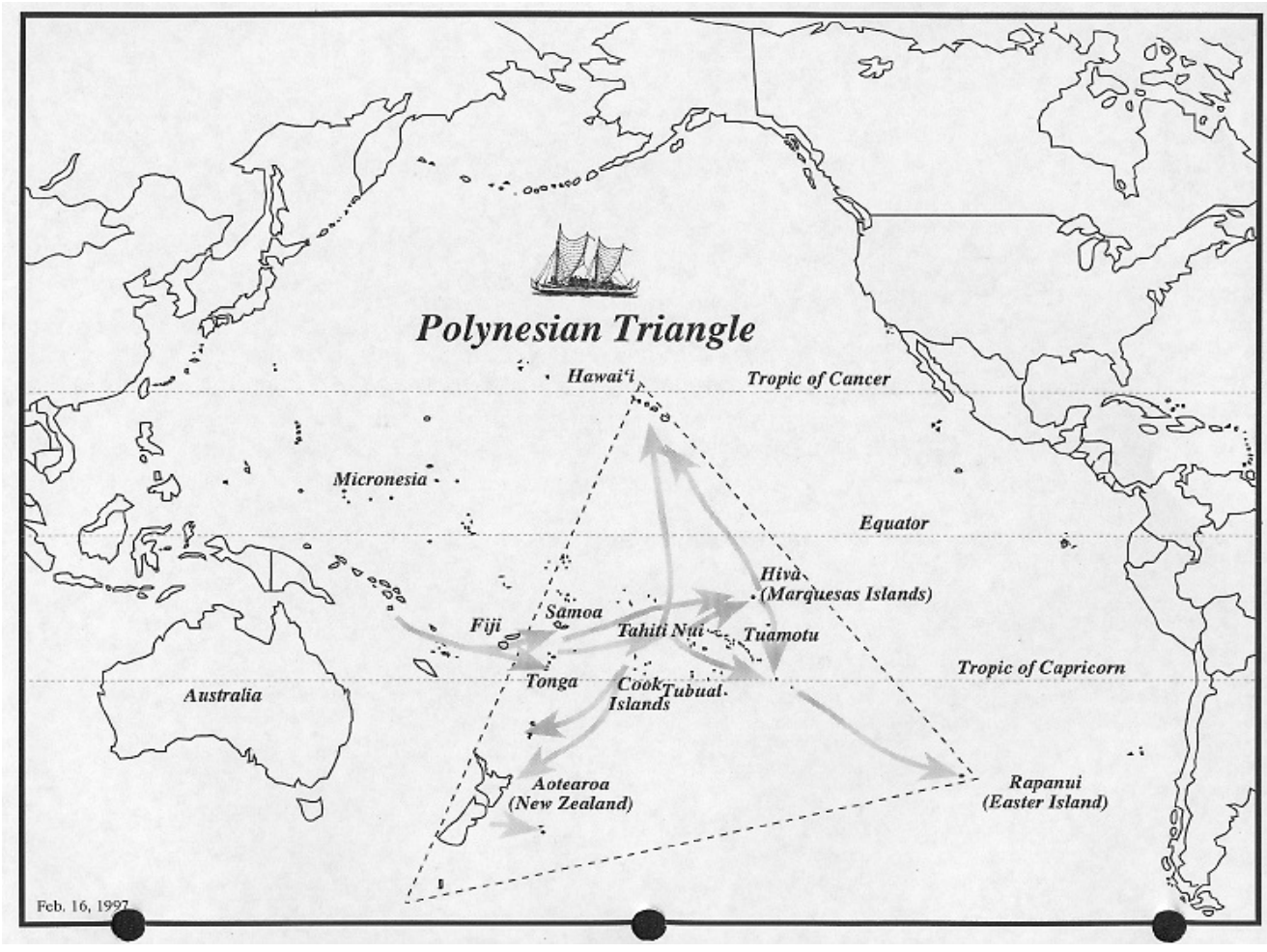

Source: The Trans-Pacific Project http://www.transpacificproject.com/ 
The Polynesian Triangle as a conceptual space enables questions to be asked about whether it could provide an operating framework for securing this particular part of the Pacific maritime domain - a framework in which US, New Zealand and France could assist the Pacific states within that space. An existing example concerns the island of Samoa. This island is split into two states - American Samoa and Samoa. The US has sovereignty over American Samoa; the independent state of Samoa was once a colony of New Zealand. American Samoa is not a state of the US. Instead, it is "unincorporated" meaning that only part of the US constitution applies to it, and "unorganized", meaning that the US Congress has not given effect to the American Samoan constitution. ${ }^{30} \mathrm{New}$ Zealand has responsibilities to support Samoa, with which it has signed a Treaty of Friendship and, more recently, a Statement of Friendship that prioritises cooperation over 'security' including maritime security, humanitarian assistance and border security. ${ }^{31}$ The similarity for the US and New Zealand is that neither American Samoa nor Samoa are subject to the courts of the US or New Zealand, respectively.

Because neither the US nor New Zealand have sovereignty over the islands of Samoa, maritime patrolling and surveillance has to be framed in terms of 'support' and 'cooperation'. In this case, cooperation is four way - bilaterally between each larger state and its Samoan partner, and bilaterally between New Zealand and the US. A 2019 rendezvous between the US Coast Guard and the New Zealand Royal Navy off the coast of Samoa and American Samoa illustrates this cooperation. ${ }^{32}$ This rendezvous was part of Operation Aiga, an ongoing operation falling under the Quadrilateral Defence Coordination Group (Pacific Quads). ${ }^{33}$ Operation Aiga is one of the few operations that is specific to the Polynesian Triangle. Comprising New Zealand, the US, France and Australia, the Pacific QUADs coordinates support in the form of maritime surveillance, particularly for combatting illegal, unreported and unregulated fishing in Pacific Island Forum Countries. ${ }^{34}$

The example of the island of Samoa illustrates the multi-dimensional nature of any engagement in the region by the US and New Zealand. It suggests a place where quite specific needs and capabilities can be brought together for non-military purposes, using the constabulary functions of military personnel and assets.

\section{Indo-Pacific}

The Polynesian Triangle is one type of Pacific bordered space. Another is the IndoPacific. The earlier example of the US interests in the South China Sea is salient to the framing of the US gaze in the Pacific as the 'Indo-Pacific'. Use of the term 'IndoPacific' in a security context can be found in the proceedings of a 2011 conference cosponsored by the US Naval War College and Lowy Institute for International Policy. ${ }^{35}$ In 2017, the term was used in the Quadrilateral Security Dialogue (the Quads) between India, Japan, US and Australia. ${ }^{36}$ Its application is both maritime and strategic in nature, putting Asia in the centre of these four countries. ${ }^{37}$ It recognises a shift from the Atlantic 
to the Indian Ocean as a key strategic maritime trade route, reflecting the growth of Asian economies and of Africa and the Middle East as key sources of raw materials and other resources. Figure 3 below illustrates the geopolitical framing created by the Quad, encircling and enclosing China.

In practice, the US's strategic focus is neither Indo, nor Pacific. It is Asia, and specifically China. The reality of this focus is highlighted by the 2018 change of name of the US Pacific Command, located in Hawai'i, to Indo-Pacific Command (INDOPACOM). This change was reported as recognising the US role in countering Chinese influence in the region..$^{38}$ The locus of Hawai'i as the point of the US gaze makes sense with this repositioning. In this context, securing the maritime domain is therefore much more about the eastern coastal areas of Asia than about either the Indian or Pacific Oceans in their wider sense.

\section{Figure 3: Quad countries.}

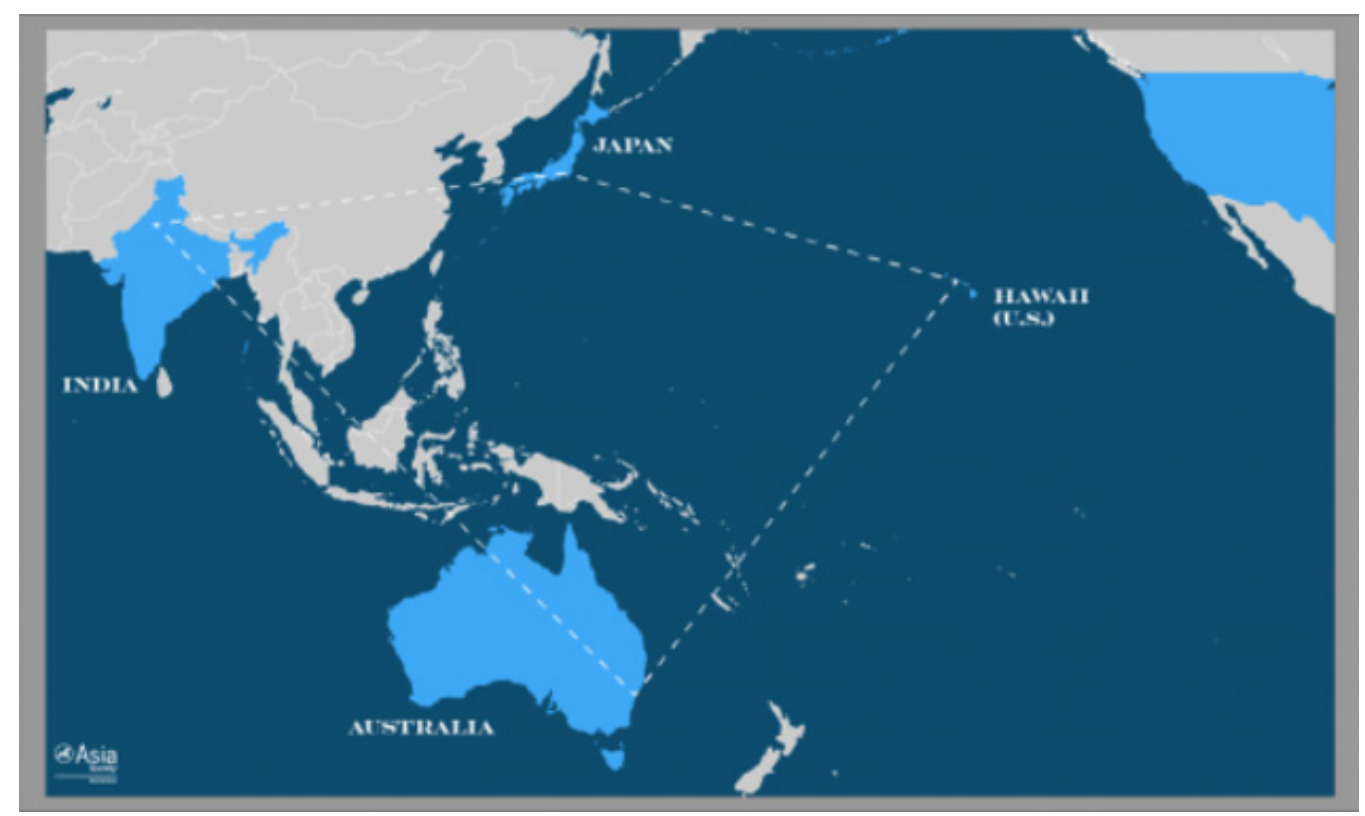

Source: Asia Society Switzerland. ${ }^{39}$

New Zealand's Pacific focus and activities continue to be in the southern hemisphere. As seen in Figure 2, New Zealand (and Polynesia, excepting Hawai'i) sits outside this quadrant, and began using the term Indo-Pacific only in 2020, having previously preferred Asia-Pacific. ${ }^{40}$ There is no denying that New Zealand is acutely conscious of China's behaviours in the Southern Hemisphere, just as the US is in the north-western 
Pacific. However, China is not the primary security focus of New Zealand's foreign affairs, nor maritime security. As Sousa-Santos told RNZ in 2019, "New Zealand is part of the Pacific, and unlike the other partners, we don't look at the hard issue of defence or geopolitics". ${ }^{41}$ Some might consider this overstated, but the order of New Zealand's seven strategic foreign policy objectives is instructive. First on the list is ensuring the international rules-based order flourishes. ${ }^{42}$ The Indo-Pacific is listed third after trade. Whether the order in which these objectives is listed is deliberate and meaningful is not stated, but as the list is not alphabetical, it suggests a downplaying of regional geopolitics. Even so, the use of the term by Rt.Hon. Winston Peters, then Minister of Foreign Affairs, in a February 2020 speech to the Indian Council of World Affairs, referred to New Zealand's broad range of interests in the region, rather than restricting it to maritime strategy. This use suggests New Zealand's interpretation of the term is deliberately beyond the military. ${ }^{43}$ Even back in 2015, in political discussions between India and New Zealand, India's use of the term was broader than that adopted by the Quads in $2017 .{ }^{44}$

The purpose of this discussion is to highlight how the 'Indo-Pacific' terminology makes visible only one aspect of the Pacific Ocean - its western edge. By doing so, it makes invisible the much more nuanced picture presented by the Pacific Ocean as a whole. For example, much less is written about the Pacific Quads. The focus of the Pacific Quads is joint co-operation and response activities across a range of security interests. As articulated by the US Coast Guard, these are "human security, environmental security, transnational and organised crime, and humanitarian assistance." ${ }^{45}$ For New Zealand, the Pacific Quads speaks more directly to New Zealand interests than the Indo-Pacific Quad (especially given it is not a member of the latter grouping). Given that US INDOPACOM sees Oceania as a strategic break point, the much lower visibility of the Pacific Quads is worth examining.

The New Zealand Defence Force (NZDF) is the key New Zealand partner in the Pacific Quads, representing the interests of New Zealand's civilian maritime agencies as well as its own. The NZDF Annual Report 2019 states that NZDF conducted joint maritime surveillance operations with Quads members in the 2018-2019 reporting year. ${ }^{46}$ The report does not specify what sorts of operations or for which agencies. Because the NZDF assets are used, civilian agency interests are less visible but the majority of NZDF patrol and surveillance activity in the South Pacific is to monitor and combat illegal fishing. ${ }^{47}$ As part of its strategic repositioning, the NZDF pointed to the success of the Pacific Quads as an example of its responsiveness to changing dynamics in the region:

The expanded scope of Pacific QUADS is a positive example of a well-consulted adjustment to more accurately reflect regional challenges and the parameters of our response. ${ }^{48}$ 
The detail of that expanded scope is not provided, but this shift has to be seen in the context of New Zealand Government's Pacific Reset as well as the 2018 Boe Declaration on Regional Security signed by Pacific Island Forum leaders. ${ }^{49}$ That Declaration includes both traditional and non-traditional security threats, and commits to strengthening the existing security architecture by a number of means, one of which is increased security co-ordination. The NZDF "Advancing Partnership in the Pacific" document addresses the latter point through more transparency of meeting outcomes. For example, the 2019 South West Pacific Heads of Maritime Forces Meeting agreed to share its outcomes with various Pacific regional organisations, including the Pacific Islands Forum Secretariat and the Pacific Islands Chiefs of Police. ${ }^{50}$ This development signals a softening of the divide between military and non-military information. The next section moves, then, to examine the non-military mechanisms of US and New Zealand's attempts at securing the Pacific maritime domain.

\section{The practicalities of maritime interests in the Pacific: The US and New Zealand}

One of the memorable experiences of the study tour to Hawai'i was boarding a US Coast Guard cutter, the USCGC Kimball, and finding out about the Coast Guard role, mandate, capability and culture. While a part of the US Department of Homeland Security, the US Coast Guard has a hybrid role in that they call themselves a military service, are interoperable with the defence forces and operate under the Navy in times of war. ${ }^{51}$ Their peace-time work focuses on responding to maritime insecurities such as piracy, transnational crime, illegal, unreported and unregulated fishing, search and rescue, pollution and environmental degradation and natural and man-made disasters - many of those areas mentioned earlier. It is clear, then, that the US Coast Guard is the primary mechanism for securing US maritime domains. Notably, this role is its primary mandate and its assets are specifically designed for it.

With such a broad mandate, understanding US priorities for the US Coast Guard is key for New Zealand. The US Coast Guard strategic plan 2018-2022 articulates a dynamic maritime strategic environment, and while its Strategic Framework aligns the Strategic Plan with the National Security Strategy, Department of Homeland Affairs Goals and Priorities and the National Defense Strategy, it does not explicitly say what activities will be the focus. ${ }^{52}$ The Strategic Plan refers briefly to the Indo-Pacific, but it is in such broad terms, that it is difficult for an outsider to interpret what this might mean in practice:

In the Indo-Pacific, we are actively building partner capacity and theater security cooperation throughout the region to enhance maritime governance and bolster stability in collaboration with United States Indo-Pacific Command (USINDOPACOM) ${ }^{53}$ 
News items in 2019 provide some clues to the US Coast Guard focus - first to a greater involvement in Oceania, and second in supporting the US Navy in the Indo-Pacific. ${ }^{54}$ The US Coast Guard priorities focus on excellence in readiness and response and recognise the complexity of maritime challenges. ${ }^{55}$

Despite their military structure and appearance and their law enforcement capabilities, the USCGC Kimball crew advised they are trusted to be neutral. By this they meant they do not receive operational incentives for intercepting illegal activities. Instead, their approach to the people caught in activities such as drug or people smuggling is people-focused. They take the time to find out the circumstances of these people and treat them with respect. In line with this approach is their ability to more easily access and work with more countries than the US Navy. Examples given were entering Cuban waters for search and rescue operations and working with China in the South West Fisheries Commission on the issue of illegal fishing. Making a contribution to their local community is also important.

The US Coast Guard in Honolulu is a sector in the Pacific Area, headquartered out of the West Coast of the US. ${ }^{56}$ The Honolulu Sector covers a wide territory - from the Midway Island and the Hawai'ian Islands in the North Pacific down to American Samoa in the South Pacific. ${ }^{57}$ This zone of operations is clearly focused on US territorial interests and related bordering activities, from the Hawai'ian Island Chain in the north to Wake Island in the west and American Samoa in the south. ${ }^{58}$ Notable from discussions about the Coast Guard role was that while seemingly well-provisioned, getting the resources and assets they needed from the US Government was always a struggle. In future, they advised, 90 percent of patrols are to monitor fisheries.

\section{New Zealand Maritime Security}

New Zealand has the fourth largest maritime zone in the world, plus a search and rescue zone that reaches from Antarctica in the south to Samoa in the north, covering over 30 million square kilometres. ${ }^{59}$ Within this zone, New Zealand has sovereign obligations to the Realm countries of Tokelau, Cook Islands and Niue. Despite New Zealand calling itself a maritime nation, historically, governments have invested surprisingly little in securing New Zealand maritime interests. ${ }^{60}$ However, security of the maritime domain is starting to gain increasing attention. The Strategic Defence Policy Statement 2018 highlighted "maritime domain awareness and response" as the first of three capability areas to be addressed. ${ }^{61}$ The Cabinet sign-off of a Maritime Security Strategy in 2019 indicates a recognition that action is needed. ${ }^{62}$

A need for a New Zealand Maritime Security Strategy was identified as far back as 2001. In 2002, a small, multi-agency unit called the National Maritime Coordination Centre (NMCC) was created to coordinate civilian patrol and surveillance needs. In the review that led to the creation of the NMCC, the New Zealand Customs Service identified the 
need for a hierarchy of maritime strategies to provide cohesion and direction to its work. ${ }^{63}$ In a review by the Office of the Auditor General in 2010, there was an explicit recommendation for a maritime strategy. ${ }^{64}$ In 2014, a maritime framework was agreed, but not a strategy. ${ }^{65}$ The strategy identifies the complexity and cross-cutting nature of New Zealand's maritime security interests, and identifies nine security drivers in the maritime environment, including escalation of trans-national organised crime, increased pressures from resource exploitation, diverse and increasing numbers of actors in the South Pacific, and climate change effects. In addition, it identifies the role of rapid technological developments that both enhance maritime security and enable criminal elements to more easily breach the ocean 'moat' that has protected New Zealand so well. ${ }^{66}$ The Strategy is built around two principles - a comprehensive multi-agency approach and kaitiakitanga ("stewardship and protection for future generations"). ${ }^{67}$

To achieve the goals of the Strategy, New Zealand does not have a dedicated set of assets, such as the US Coast Guard. Instead, the Royal New Zealand Navy and Royal New Zealand Air Force carry out maritime patrols on behalf of civilian agencies in a programme coordinated by the NMCC, hosted by the New Zealand Customs Service and co-located with Joint Force Headquarters at Trentham, Wellington. ${ }^{68}$ These patrols and surveillance are fitted around New Zealand Defence Force military priorities. Bridging military and civilian interests and priorities, the NMCC thus plays an important role in helping New Zealand get the best use from its small maritime fleet, in managing its large maritime area of responsibility. As well as patrolling and surveillance of New Zealand's maritime zones, military assets are deployed to the Southern Ocean and the Pacific Islands for a range of reasons including deterring, detecting and interdicting illegal, unreported and unregulated (IUU) fishing, responding to natural disasters and conducting search and rescue patrols.

Juggling civilian maritime patrol and surveillance with core military activities is a challenge and a tension for the NZ Defence Force. While focusing on core military combat-readiness, the Strategic Defence Policy Statement 2018 introduced ideas of 'resilience' for New Zealand and the South Pacific in the face of non-military disruptors such as climate change, transnational crime and resource competition. ${ }^{69}$ At a practical level, military operational planning occurs three to five years in advance; civilian planning tends to be annual at best, and sometimes month to month. ${ }^{70}$ These different planning time frames create a challenging environment, compounded by the different organisational paradigms in defence forces and civilian agencies.

What is notable about these two approaches to securing non-military maritime interests is that the US operational capabilities are dedicated to these interests while New Zealand's are split between military and non-military. The differences in structure influence US-New Zealand co-operation in the southern part of the Pacific. The US Coast Guard has a flexibility absent from New Zealand's arrangements. It is an integrated force with a unified culture that is able to plan for and respond to any of the maritime 
threats in its mandate, whereas for New Zealand, the Navy's constabulary work via the NMCC has to be 'fitted in' to its military work. It also requires military personnel to adopt a different mind-set when conducting non-military operations such as fisheries surveillance. The increased focus on Pacific and Antarctica in the Strategic Defence Policy Statement 2018 moves that work closer to 'military' work, but very much at the constabulary end of the spectrum. ${ }^{71}$ Within these operational and structural differences, the New Zealand military and the NMCC have an international relationship with the US Coastguard, working together to combat the same sorts of threats and risks. ${ }^{72}$ The practical effect of the differences and whether there is an opportunity to better leverage the advantages of each approach within a bordered theatre of cooperation is worthy of further research.

\section{The special case of Antarctica}

One area that is rarely included as part of the Pacific, but that sits squarely within the Realm of New Zealand through the Ross Dependency territorial claim is Antarctica. While not geographically connected to the US as for New Zealand, Antarctica could also be considered part of the US's Pacific. The US has the largest station on Antarctica in the McMurdo Station, with over 1200 people on the station at the summer peak. ${ }^{73}$ New Zealand and the US are both foundation signatories of the Antarctic Treaty of 1959. While the US does not have a territorial claim, the Treaty provides an opaque space for a future claim by the US and Russia in its Article IV. ${ }^{74}$

On Antarctica, McMurdo station is three kilometres from New Zealand's Scott Base. ${ }^{75}$ As such, New Zealand benefits from significant US logistics support. This support is underpinned by a longstanding formal Memorandum of Understanding that has enabled the US to establish and operate a transit facility out of Christchurch. ${ }^{76}$ This physical closeness, combined with the closeness from being part of the negotiation of the Antarctic Treaty, provides a strong New Zealand-US connection in relation to Antarctica.

Practically, co-operation occurs in several geographical spaces. The first space is Pearl Harbour in Hawai'i, where the US military logistical support for Antarctica carried out by Joint Task Forces - Support Forces Antarctica, better known as Operation Deep Freeze, is based. ${ }^{77}$ The second is Coast Guard Pacific Area Cutter Polar Star, which cuts a path through the ice each Antarctic summer (November to March) to enable supply ships to access McMurdo Station. The Polar Star is directed out of Seattle, Washington and operationally launched from California, not Hawai'i. ${ }^{78}$ The difference is likely because the Polar Star services the Arctic as well as the Antarctic. The third space is the US National Science Foundation Antarctic Programme in Christchurch, New Zealand. It operates out of a secure area within the Christchurch International Airport precinct from which US Antarctic flights depart and arrive back. 
In the special case of Antarctica, we see Pacific maritime connections that start from mainland US, reach across the Polynesian Triangle and down to Antarctica. This more peaceful Eastern Pacific view contrasts starkly with the geopolitical tensions of the Western Pacific and shows a space where the US and New Zealand focus is more aligned. It is also one part of the world where New Zealand conducts maritime surveillance and patrol and the US does not. ${ }^{79}$ This difference provides a point of leverage for cooperation, as discussed above.

\section{Implications for securing Pacific maritime domains}

This article has shown that while the Pacific Ocean is a highly bordered space, there are several ways in which state control is difficult. First, much of the Pacific is open seas, particularly north of the Equator, and so full state control is limited to the actions of its flagged vessels. Second, the maritime environment is mobile - the sea itself, the fish within it, the vessels moving upon it and information moving invisibly above and beneath it. Securing this environment is by necessity dynamic and unpredictable, requiring sophisticated technologies and other capabilities for response activities. Third, Pacific Ocean borders are not just territorial; they are also cultural. US and New Zealand interests may not align with those of Pacific Island states they wish to influence. These different border elements suggest not just a bordered space, but a borderscape. A borderscape draws a picture of borders as fluid, performative spaces in which social interactions create changing ideas of 'insiders' and 'outsiders', institutional frameworks structure control of those interactions, and multiple actors experience bordering practices in different ways and in different places ${ }^{80}$ Transferring the borderscape concept from land to the sea is useful for bounding areas of cooperation within the theatre of the Pacific Ocean; for situating traditional and cultural practices alongside western notions of maritime security; for ensuring multiple voices are heard.

Considering the Pacific as a maritime borderscape gives more prominence to a growing Pacific Island assertiveness, with Pacific Island countries reclaiming their Pacific spaces and practices from colonial powers. ${ }^{81}$ Numerous regional institutional frameworks provide mechanisms for protecting maritime spaces, some of which are led by the Pacific Island states themselves, as in the Forum Fisheries Agency, and some that are led by the colonial powers, such as the Pacific Quads. Maritime threats addressed through these mechanisms are the rich fishery resources, vulnerable to IUU fishing, and flows of transnational criminals who increasingly use Pacific countries as hubs through which to transport illicit drugs from Asia and Central and South America to New Zealand and Australia. ${ }^{82}$ These island states benefit from US and New Zealand capabilities for surveillance of the EEZs, but exercising these capabilities has to be at the request of those states. Securing the Pacific Ocean is no longer a colonising space 
within which larger states are free to exercise their power. ${ }^{83}$ In this sense, the locus of power is shifting from colonial states to Pacific Island states, which in turn affects the answer to the question 'whose security?'

Within this shifting borderscape, US and New Zealand fixations on the actions of 'outsider' countries such as China and Russia become secondary. Instead, the more important task is to more clearly articulate where US and New Zealand can legitimately cooperate in response to the needs of Pacific Island states. A zone of interest such as the Polynesian Triangle could be worth exploring as a borderscape. Not only could it provide a defined space to address the where, what, why, for whom and how of maritime security, but it could also give more prominence to the non-military security aspects of maritime security and to indigenous interests and practices. The starting point for this newly framed maritime security space would not be US or New Zealand defence priorities, but rather Pacific Island maritime security priorities, building on the Boe Declaration. ${ }^{84}$ New Zealand Defence Force's "Advancing Pacific Partnerships" document demonstrates a shift in this direction is already occurring, with its priorities specifically aligned with that Declaration. ${ }^{85}$

\section{Conclusion}

This article set out to answer the question "How are US and New Zealand maritime security interests bordered in the Pacific and what are the implications?" First, it has shown that geography matters. Visualising one's location on a map orients one towards the rest of the world. In the case of New Zealand, its view covers the breadth of the Pacific Islands below the equator, Australia and Antarctica to the south. The cartographic representation of this space causes New Zealanders to 'look up' at the rest of the world and 'down' to Antarctica. From Hawai' i, the view is quite different. The Asian and American continents surround it; below is Polynesia. America is 'home'; Asia is not. In the oceanic world of the Pacific, one's viewpoint determines one's approach to the control of maritime spaces.

Second, it has shown that through UNCLOS, the Pacific maritime domain contains multiple border zones, where degrees of sovereign control differ. The securing of the Pacific maritime domain as a borderscape folds in multiple actors, multiple sovereignties, multiple types of control and multiple intentions. It recognises all actors without prejudice. What becomes important is how they interact and what happens to security as a result. In this space, military interests are only one part of a much greater whole.

Third, a Pacific maritime borderscape is dynamic, reflecting the fluidity of the ocean itself and the fluidity of political, military and non-military interests and interactions. Understanding the extent and interplay of the Pacific borderscape is essential if cooperation between US and New Zealand is to engender meaningful and lasting results. 
Implicit in these insights is the need for movement in the area of US-New Zealand cooperation. Questions such as 'whose Pacific?', 'whose security?' and 'for what purpose?' are important but not adequate. Questions that prompt a shift of gaze to less visible aspects of the maritime domain such as non-military interests or alternatives to existing practices emerge from the borderscape concept. As such, further areas of research suggest themselves, such as a potential role for indigenous practices (including Hawai'ian) in securing maritime domains, the nature of existing New Zealand and US maritime cooperation, the results achieved and areas for development, and scope for more visibility of non-military activities in forums such as the Pacific Quads. 
1 Jae-Hyung Lee, "China's Expanding Maritime Ambitions in the Western Pacific and the Indian Ocean," Contemporary Southeast Asia 24:3 (2002), pp.549-68; Christian Wirth, "Whose "Freedom of Navigation'? Australia, China, the United States and the Making of Order in the 'Indo-Pacific,"” The Pacific Review 32: 4 (July 4, 2019), pp.475-504. DOI:10.1080/09512748.2018.1515788; David C. Gompert, "U.S. and Chinese Interests and Sea Power in the Western Pacific," in Sea Power and American Interests in the Western Pacific (RAND Corporation, 2013), 69-118. https://www.jstor.org/ stable/10.7249/j.ctt2tt8zr.11. \uc0 \lu8221\{\}\{\\i\{\}Contemporary Southeast Asia\} 24, no. 3 (2002)

2 Pacific Islands Forum Secretariat, "Boe Declaration on Regional Security," Pacific Islands Forum Secretariat, September 5, 2018, https://www.forumsec.org/2018/09/05/boe-declaration-on-regional-security/.

3 John Agnew in Tugba Basaran et al., International Political Sociology: Transversal Lines (Routledge, 2016).

4 Robert D. Sack, "Human Territoriality: A Theory," Annals of the Association of American Geographers 73: 1 (March 1, 1983), pp. 55-74. DOI:10.1111/j.1467-8306.1983.tb01396.x. \\uc0 \u8220\{\} Human Territoriality: A Theory, $\mid \backslash u c 0 \backslash \backslash u 8221\{\}\{\backslash \backslash i\{\}$ Annals of the Association of American Geographers $\}$ 73, no. 1 (March 1, 1983

5 Corey Johnson et al., "Interventions on Rethinking 'the Border' in Border Studies," Political Geography 30:2 (February 1, 2011), pp. 61-69. DOI:10.1016/j.polgeo.2011.01.002.

6 Henk Van Houtum, Olivier Thomas Kramsch, and Wolfgang Zierhofer, eds., Bordering Space, Border Regions Series (Aldershot, Hants, England ; Burlington, VT: Ashgate, 2005). https://henkvanhoutum. nl/wp-content/uploads/2013/05/borderingspace.pdf.

7 Matías Iglesias, "UNCLOS and Territorialization of the Seas: The Case of Indian and Pacific Oceans," Journal de Ciencias Sociales, 9 (October 1, 2017). DOI:10.18682/jcs.v0i9.659.

8 Barry J. Ryan, "The Disciplined Sea: A History of Maritime Security and Zonation," International Affairs 95:5 (September 2019), p.1067. DOI:10.1093/ia/iiz098.

9 United Nations, "United National Convention on the Law of the Sea" (United Nations, 1982), https://www.un.org/depts/los/convention_agreements/texts/unclos/unclos_e.pdf.

10 "Tensions in the East China Sea," Council on Foreign Relations, Global Conflict Tracker, November 25, 2020, https://cfr.org/global-conflict-tracker/conflict/tensions-east-china-sea; "Territorial Disputes in the South China Sea," Global Conflict Tracker, accessed November 27, 2020. https://cfr.org/global-conflict-tracker/conflict/territorial-disputes-south-china-sea.

11 Leland Holbrook Smith, "To Accede or Not to Accede: An Analysis of the Current US Position Related to the United Nations Law of the Sea," Marine Policy 83 (September 1, 2017), pp.184-93. DOI:10.1016/j.marpol.2017.06.008.though the United States (US

12 Dana D. Miller and U. Rashid Sumaila, "Flag Use Behavior and IUU Activity within the International Fishing Fleet: Refining Definitions and Identifying Areas of Concern," Marine Policy 44 (February 1, 2014), pp.204-11. DOI:10.1016/j.marpol.2013.08.027.

13 "Security Spheres: A Phenomenology of Maritime Spatial Practices - Barry J Ryan, 2015." DOI:10.1177/0967010615598049.

14 Ryan, "The Disciplined Sea," 1056.

15 Lawrence Freedman, Strategy : A History (Oxford: Oxford University Press, 2013).

16 Compare, for example, with border security, where 'border' is a noun; or 'human security', where 'human' is a noun

17 Christian Bueger, "What Is Maritime Security?”. Marine Policy 53 (March 1, 2015), pp.159-64. DOI:10.1016/j.marpol.2014.12.005.

18 Vladimir Kolossov and James Scott, "Selected Conceptual Issues in Border Studies," Belgeo. Revue Belge de Géographie, 1 (November 4, 2013). DOI:10.4000/belgeo.10532.

19 Steven C. Boraz, "Maritime Domain Awareness," Naval War College Review 62:3 (2009), pp.13746. http://www.jstor.org/stable/26397039.

20 David K. C. Huang, "US Foreign Policy Regarding the Defence of Taiwan: A Critical Analysis in Accordance with US Law," Asian Journal of Political Science 28:3 (September 1, 2020), pp.256-74. DO I: 10.1080/02185377.2020.1774910.

21 "Barry Returns to the South China Sea," Government of United States, United States Navy, November 22, 2020. Available at https://www.navy.mil/Press-Office/News-Stories/Article/2424168/barry-returns-to-the-south-china-sea/. 
22 "Tensions Rise in the South China Sea: US, Chinese Maneuvers in Neighboring Waters," News, nippon.com, August 13, 2020. Available at https://www.nippon.com/en/in-depth/d00601/.

23 Chris Trelawny, "Maritime Security Beyond Military Operations," The RUSI Journal 158:1 (February 1, 2013), pp.48-52. DOI:10.1080/03071847.2013.774639.

24 Chris Rahman, "Concepts of Maritime Security A Strategic Perspective on Alternative Visions for Good Order and Security at Sea, with Policy Implications for New Zealand," Discussion paper (Wellington, N.Z: Centre for Strategic Studies, Victoria University of Wellington, 2009). https://www.wgtn.ac.nz/ strategic-studies/documents/discussion-papers/concepts-of-maritime-security-dp-07-09.pdf.

25 Boraz, "Maritime Domain Awareness."

26 National Geographic Society, "Plate Tectonics and the Ring of Fire," National Geographic Society, January 6, 2015, http://www.nationalgeographic.org/article/plate-tectonics-ring-fire/.

27 Robert Ayson, "New Zealand and the Great Irresponsibles: Coping with Russia, China and the US," Australian Journal of International Affairs 74:4 (2020), pp.455-78. DOI:10.1080/10357718.2020.17347 73.

28 Patrick Vinton Kirch, "Reflections," in Unearthing the Polynesian Past : Explorations and Adventures of an Island Archaeologist, Ebook (Hawai'i: University of Hawai'i Press, 2016). http:// hawaii.universitypressscholarship.com/view/10.21313/hawaii/9780824853457.001.0001/upso-9780824853457-chapter-024.

29 Linda W. Greene, "A Cultural History of Three Traditional Hawaiian Sites on the West Coast of Hawai'i Island (Chapter 1)," Government of United States, National Park Service, 1993. http://npshistory. $\mathrm{com} /$ publications/hawaii/greene/chap1.htm.

30 Edward J. Michal, "American Samoa or Eastern Samoa? The Potential for American Samoa to Become Freely Associated with the United States," The Contemporary Pacific 4:1 (1992), p.139. https:// scholarspace.manoa.hawaii.edu/bitstream/10125/8550/v4n1-137-160.pdf.

31 Government of New Zealand and Government of Samoa, "New Zealand-Samoa Statement of Partnership 2019-2023," February 5, 2019. https://www.mfat.govt.nz/assets/Countries-and-Regions/Pacific/ Samoa/New-Zealand-Samoa-Statement-of-Partnership-2019-2023.pdf.

32 "U.S. Coast Guard, Royal New Zealand Navy Conduct Professional Exchanges in Oceania," Homeland Security Today. US, August 15, 2019. Available at https://www.hstoday.us/subject-matter-areas/ maritime-security/u-s-coast-guard-royal-new-zealand-navy-conduct-professional-exchanges-in-oceania/.

33 "U.S. Coast Guard, Royal New Zealand Navy Conduct Professional Exchanges Amid Operations In," Government of United States, U.S. Indo-Pacific Command, August 14, 2019. Available at https:// www.pacom.mil/Media/News/News-Article-View/Article/1934409/us-coast-guard-royal-new-zealandnavy-conduct-professional-exchanges-amid-opera/.

34 Pacific Islands Forum Fisheries Agency, "Integrated Aerial Surveillance as Part of the Australian Government Pacific Maritime Security Program," Intergovernmental, United Nations Oceans Conference, 2017, https://oceanconference.un.org/commitments/?id=18793.

35 Thomas G. Mahnken, Indo-Pacific Maritime Security in the 21st Century; Proceedings of an International Conference (Sydney: Lowy Institute for International Policy, 2011). https://www.lowyinstitute. $\mathrm{org} / \mathrm{sites} /$ default/files/indo-pacific_maritime_security_in_the_21st_century_0.pdf.

36 "Far from Geography: A «Free and Open Indo-Pacific»," Asia Society, 2018. Available at https:// asiasociety.org/switzerland/far-geography-free-and-open-indo-pacific.

37 Rory Metcalf, "Reimagining Asia: From Asia-Pacific to Indo-Pacific," in International Relations and Asia's Southern Tier: ASEAN, Australia, and India, ed. Gilbert Rozman and Joseph Chinyong Liow, ebook (Singapore: Palgrave Macmillan, 2018), pp.9-28. https://link-springer-com.ezproxy.massey.ac.nz/ book/10.1007\%2F978-981-10-3171-7.

38 “INDOPACOM, It Is: US Pacific Command Gets Renamed," Defense News, May 30, 2018. Available at https://www.militarytimes.com/news/your-military/2018/05/30/indo-pacom-it-is-pacific-command-gets-renamed/.

39 Welti and Woker, "Far from Geography."

40 "New Zealand Picks up on the Indo-Pacific," Asia Pacific Bulletin (Washington DC, March 17, 2020), Available at https://www.eastwestcenter.org/publications/new-zealand-picks-the-indo-pacific.

41 “NZ's Drug Issues Fuelling Problems in Pacific, Warns Expert," Media, RNZ, July 31, 2019. Available at https://www.rnz.co.nz/international/pacific-news/395661/nz-s-drug-issues-fuelling-problems-inpacific-warns-expert. 
42 New Zealand Ministry of Foreign Affairs and Trade, "Our Strategic Direction," New Zealand Ministry of Foreign Affairs and Trade, https://www.mfat.govt.nz/en/about-us/our-strategic-direction/.

43 For example, MFAT included Republic of Korea and Vietnam in its use of "Indo-Pacific Partners": New Zealand Ministry of Foreign Affairs and Trade, "COVID-19 Coordination with Indo-Pacific Partners," New Zealand Ministry of Foreign Affairs and Trade, May 20, 2020. https://www.mfat.govt.nz/en/ media-and-resources/news/covid-19-coordination-with-indo-pacific-partners/.

44 Mark G. Rolls, “Opposites Attract? India-New Zealand Relations in the Contemporary Indo-Pacific,” Political Science 68:1 (June 1, 2016), pp.78-95. DOI:10.1177/0032318716650554.

45 New Zealand Defence Force, "Advancing Pacific Partnerships 2019: A Framework for Defence's Approach to the Pacific" (New Zealand Government, October 2019), 20. https://www.defence.govt.nz/ assets/publication/file/5f6dd307e7/Advancing-Pacific-Partnerships-2019.pdf.

46 New Zealand Defence Force, “Annual Report 2019” (New Zealand Defence Force, 2019). https:// www.nzdf.mil.nz/assets/Publications/NZDF-Annual-Report-2019.pdf.

47 New Zealand Defence Force.

48 New Zealand Defence Force, “Advancing Pacific Partnerships 2019,” 21.

49 Pacific Islands Forum Secretariat, "Boe Declaration on Regional Security."

50 New Zealand Defence Force, "Advancing Pacific Partnerships 2019."

51 US Department of Defense, "Our Forces," Government of United States, U.S. Department of Defense, https://www.defense.gov/Our-Story/Our-Forces/.

52 US Coast Guard, "US Coast Guard Strategic Plan 2018-2022" (US Coast Guard, 2018), https:// media.defense.gov/2018/Nov/16/2002063979/-1/-1/0/USCG_STRATEGIC\%20PLAN_LORES\%20 PAGE_20181115_VFINAL.PDF.

53 US Coast Guard, 6.

54 “U.S. Coast Guard Mulling More Operations in Oceania,” News, USNI News, October 22, 2019. Available at https://news.usni.org/2019/10/22/u-s-coast-guard-mulling-more-operations-in-oceania; "What Is the US Coast Guard's Role in the Indo-Pacific Strategy?," Newspaper, The Diplomat, June 21, 2019. Available at https://thediplomat.com/2019/06/what-is-the-us-coast-guards-role-in-the-indo-pacificstrategy/.

55 US Coast Guard, "US Coast Guard Strategic Plan 2018-2022."

56 United States Coast Guard, "United States Coast Guard (USCG) - Pacific Area," Government of United States, US Coast Guard, US Department of Homeland Security, accessed January 11, 2021. https://www.pacificarea.uscg.mil/.

57 US Coast Guard, "Sector Honolulu Area of Responsibility," Government of United States, US Coast Guard, US Department of Homeland Security, accessed January 11, 2021. https://www.pacificarea.uscg. mil/Our-Organization/District-14/D14-Units/Sector-Honolulu/Sector-Honolulu-AOR/.

58 US Coast Guard.

59 US Coast Guard.

60 Michael Blades, "Focusing New Zealand's Approach to Maritime Domain Security" (Masters Thesis, Wellington, N.Z, Massey University, 2014), https://mro.massey.ac.nz/bitstream/handle/10179/7575/02_whole.pdf.

61 New Zealand Government, "Strategic Defence Policy Statement 2018" (Ministry of Defence, New Zealand, July 2018), 8. https://www.defence.govt.nz/assets/Uploads/8958486b29/Strategic-Defence-Policy-Statement-2018.pdf.

62 Maritime New Zealand, "Briefing to the Incoming Minister," Ministerial briefing (Maritime New Zealand, 2020). https://www.maritimenz.govt.nz/about/documents/Briefing-incoming-minister-2020.pdf.

63 John Secker, "New Zealand Customs Service Maritime Enforcement Needs" (Wellington, N.Z: New Zealand Customs Service, February 2001). http://www.dpmc.govt.nz/sites/all/files/publications/annex iv_customs.pdf.

64 Controller and Auditor General, "Effectiveness of Arrangements for Co-Ordinating Civilian Maritime Patrols" (Wellington, N.Z: Office of the Auditor General, 2010). https://oag.parliament.nz/2010/ maritime-patrols.

65 Blades, "Focusing New Zealand's Approach to Maritime Domain Security." 
66 Maritime New Zealand, "Maritime Security Strategy: Guardianship of Aotearoa New Zealand's Maritime Waters - Te Kaitiakitanga o Tangaroa" (New Zealand Government, 2020). https://www.transport.govt.nz//assets/Uploads/Report/MaritimeSecurityStrategy.pdf.

67 Maritime New Zealand, 17.

68 Royal New Zealand Air Force, "Eyes in the Sky," Air Force News (Wellington, N.Z.: July 2015).

69 New Zealand Government, "Strategic Defence Policy Statement 2018," 7.

70 Personal experience of the author with the creation of the NMCC in 2001-2 and development of a Maritime Patrol Framework in 2012-13.

71 New Zealand Government, "Strategic Defence Policy Statement 2018."

72 Informal discussion by the author with National Maritime Coordination Centre official

73 Kelli Mars, "McMurdo Station,” Text, NASA, June 5, 2018. http://www.nasa.gov/analogs/nsf/mcmurdo-station.

74 Antarctic Treaty Secretariat, Compilation of Key Documents of the Antarctic Treaty System, Third (Buenos Aires: Antarctic Treaty Secretariat, 2017). https://documents.ats.aq/atcm40/ww/ATCM40_ ww014_e.pdf.

75 LEARNZ, “Scott Base,” LEARNZ, https://www.learnz.org.nz/antarctica174/bg-standard-f/scottbase.

76 New Zealand Government and United States Government, "Memorandum of Understanding" (New Zealand Government and United States Government, 1958).

77 National Science Foundation, “About USAP Participants," United States Antarctic Program, https://www.usap.gov/aboutusapparticipants/.

78 John Weekes, "Cocaine Submarine Seized," Press, The, September 26, 2019, 11; United States Coast Guard, "History," US Coast Guard, US Department of Homeland Security, https://www.pacificarea.uscg.mil/Our-Organization/Area-Cutters/CGC-Polar-Star/History/.

79 New Zealand Defence Force, "HMNZS Otago Ends Patrol of Southern Ocean," Government of New Zealand, New Zealand Defence Force, December 20, 2017. https://medium.com/@nzdefenceforce/ hmnzs-otago-ends-patrol-of-southern-ocean-f996254a7d31.

80 Chiara Brambilla, "Exploring the Critical Potential of the Borderscapes Concept," Geopolitics 20:1 (January 2015), pp.14-34. DOI:10.1080/14650045.2014.884561.

81 Anna Powles and Michael Powles, "New Zealand's Pacific Policies - Time for a Reset?," New Zealand International Review 42:2 (March 1, 2017). pp.16-21. https://search.informit.org/doi/10.3316/ INFORMIT.667450107665579.

82 Rovoi, "NZ's Drug Issues Fuelling Problems in Pacific, Warns Expert."

83 Suvendrini Perera, "A Pacific Zone? (In)Security, Socereignty, and Stories of the Pacific Borderscape," in Borderscapes: Hidden Geographies and Politics at Territory's Edge, ed. Prem Kumar Rajaram and Carl Grundy-Warr (Minneapolis, United States: University of Minnesota Press, 2007), http:// ebookcentral.proquest.com/lib/massey/detail.action?docID=340771.

84 Pacific Islands Forum Secretariat, "Boe Declaration on Regional Security."

85 Harman, "The Real Threat to the Pacific." 